\title{
Review: Comparative of monitoring estrus cycle in livestock: Hormonal features and ultrasound
}

\author{
Hasbi Hasbi ${ }^{* 1)}$ and S. Gustina ${ }^{2)}$ \\ ${ }^{1)}$ Animal Production Department, Faculty of Animal Science, Hasanuddin University, Jl. \\ Perintis Kemerdekaan Km. 10, Makassar, 90245. Indonesia \\ ${ }^{2)}$ Animal Science, Faculty of Animal Husbandry and Fisheries, University of West Sulawesi, \\ Majene 91412, Indonesia
}

Submitted: 11 February 2019, Accepted: 28 January 2020

\begin{abstract}
The estrus cycle is a period in which a female animal shows the ability to become pregnant, and this event will continue over some time. The estrus cycle has two different phases, the follicular phase characterized by the presence of graffian follicles which are classified as proestrus and estrus stages or periods from regression of the corpus luteum to ovulation, and luteal phase which is characterized by the presence of the corpus luteum which is classified as the metestrus and diestrus stage or period of ovulation to the corpus luteum regression. Proestrus is chained by decreasing the concentration of progesterone, followed by increasing the concentration of estradiol. Estrus is generally characterized by a very low concentration of progesterone, an increase in the concentration of $\mathrm{LH}$, and a decrease in the concentration of estrogen. Metestrus is characterized by a low concentration of progesterone. Diestrus is characterized by an increase in the concentration of progesterone and an increase in steroid hormone production along with the maturation of the corpus luteum. The purpose of this review is to discuss the comparative monitoring of the estrus cycle in buffalo, dairy cows, sheep and camels related to hormonal features and ultrasonography.
\end{abstract}

Keywords: estrus cycle; hormonal features; ultrasound

\footnotetext{
*Corresponding Author: hasbi_fapetunhas@yahoo.com
} 


\section{INTRODUCTION}

The estrus cycle is the period in which a female animal shows the ability to become pregnant, and this event will continue to repeat at a specific period. Each estrus cycle consists of a short follicular phase and a long luteal phase. The follicular phase is dominated by the presence of hormone estradiol secreted from follicles that develop in the ovary which will cause the female animal to show changes in its reproductive organs and will show the symptoms of estrus which will be followed by the female animal's willingness to accept males. While the luteal phase is dominated by the presence of hormone progesterone which is secreted by the corpus luteum from the ovary which will affect the female reproductive organs to prepare for pregnancy and inhibit sexual receptivity. The period of estrus cycle stops known as anestrus, where this anestrus can be caused by pregnancy, season, lactation, stress, and pathology (Senger, 2005).

The estrous cycle begins with the release of gonadotropin-releasing hormone $(\mathrm{GnRH})$ from the hypothalamus, which in turn causes the release of stimulating follicle hormone (FSH) from the anterior pituitary gland which will stimulate follicular growth. The growth of follicles starts from the recruitment of primary follicles which will then develop into the antral stage, which have a cavity filled with fluid and then will become the dominant follicle which will continue to develop into pre-ovulatory follicles. The mechanism governing follicular development and selection of dominant follicles is controlled by the production of inhibin from the dominant follicle which locally will limit the response of other follicles where the remaining antral follicles will stop growing and will experience atression while at the level of the pituitary will limit the release of FSH. The development of pre-ovulation follicles will regulate estrogen production by internal theca cells and layers of granulosa cells from the follicle. The estrogen hormone has three main functions: initiation of estrous behavior, preparing the reproductive tract for the process of fertilization, and initiation of peak luteinizing hormone (LH) for ovulation (Ball and Peters 2004).

Based on the explanation above, it shows us that the estrous cycle is controlled by various types of hormones, including GnRH, FSH, Estradiol, and Progesterone. Also, it provides information and opportunities for us to monitor and manipulate the estrous cycle. In this paper, we focus on how to monitor estrus cycles both invasive and non-invasive in some domestic animals with some hormonal manipulation to start the estrus cycle so that it makes it easier to monitor the estrus cycle.

\section{Estrus Cycle}

Estrus is a condition in which female animals are willing to accept males for mating, which is usually followed by ovulation (Bridges, 2010). While the estrus cycle is a period in which a female animal shows the ability to become pregnant, and this event will continue to repeat at a particular period (Senger, 2005). Nebel et al. (1994) explain that the estrus cycle has two distinct phases, the follicular phase which is characterized by the presence of graffian follicles which are classified as the proestrus and estrus stages, or the period of regression of the corpus luteum to ovulation and the luteal phase which is characterized by the presence of corpus luteum which is classified as metestrus and diestrus stage or period from ovulation to corpus luteum regression (Fig 1).

Proestrus is characterized by regressions of corpus luteum and decreased concentration of progesterone followed by the growth of preovulatory follicles and increased concentration of estradiol. Estrus is generally characterized by a very low concentration of progesterone, an increase in the concentration of $\mathrm{LH}$, and a decrease in the concentration of hormone estrogen from a high concentration that is only reached before estrus. The estrus period lasts from 6 to $30 \mathrm{~h}$ with an average of 
$20 \mathrm{~h}$. Metestrus is characterized by the development of corpus luteum; the concentration of progesterone is still low, ovulation occurs about 10 to $15 \mathrm{~h}$ after the end of estrus. Metestrus period lasts 3 to 5 d. Diestrus is characterized by the presence of corpus luteum, an increase in the concentration of progesterone at the beginning of this period, and an increase in the production of steroids as the corpus luteum matures. The diestrus period lasts about $12 \mathrm{~d}$ (Bridges, 2010).

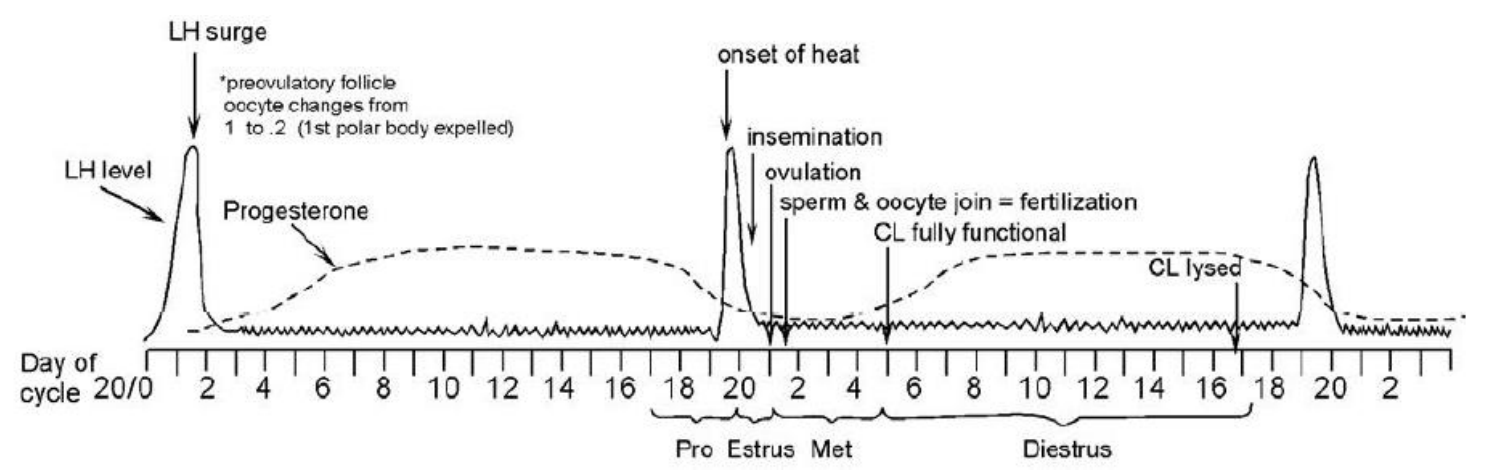

Figure 1. Scheme of estrus cycle stage (two cycles and the beginning of the third cycle). Luteinizing hormone (LH), corpus luteum (CL)

(Source: Sahatpure and Patil, 2008)

\section{Monitoring Of Ovarium Activity In Buffalo}

Ovarian acyclicity is a significant problem in reproduction and is also one of the main causes of infertility in water buffalo (Das and Khan, 2010; Zicarelli, 2010; Khan et al., 2012). This condition is the main cause of buffalo anestrus, especially during the summer in the tropics and subtropics area. This can cause substantial economic losses both to farmers and industry (Nanda, Brar, and Prabhakar, 2003). Estrogen, progesterone and insulin are known to be hormones that play a role in the ovarian activity. It was further reported that the concentrations of these hormones in cyclic and non-cyclic water buffalo correlated with the magnitude of the corpus luteum, as presented in Fig. 2.

Figure 2 showed that the concentration of estradiol in follicular fluid is lower in the acyclic buffalo (1.4 \pm $0.09 \mathrm{ng} / \mathrm{mL})$ compared to the cyclic $(3.3 \pm$ $0.18 \mathrm{ng} / \mathrm{mL})$. This is in line with was previously reported by Eissa (1996) that the concentration of estradiol in cyclic buffaloes was higher than that of acyclic. Whereas the estradiol concentrations in both cyclic or acyclic higher increase with increasing follicular size, ie $2.4 \pm$ $0.16 \mathrm{ng} / \mathrm{mL}, 2.8 \pm 0.29 \mathrm{ng} / \mathrm{mL}$, and $3.5 \pm$ $0.41 \mathrm{ng} / \mathrm{mL}$ respectively for the small, medium and large follicles. Hafez, Jainudeen, and Rosnina (2000) reported that the hormone estradiol is main hormone that responsible for the appearance of signs of estrus in domestic animals including buffalo. In addition, progesterone concentrations were also higher in acyclic buffaloes $(24.3 \pm 2.61 \mathrm{ng} / \mathrm{mL})$ compared to cyclic $(7.6 \pm 0.79 \mathrm{ng} / \mathrm{mL})$.

The high concentration of follicular fluid progesterone in acyclic buffalo is thought to be caused by the reduced conversion of progesterone to androgens or aromatization of androgens to estradiol (Das and Khan 2010). It was further explained that the acyclic buffalo showed that insulin concentration was lower in the follicular fluid than in the cyclic buffalo $(15.2 \pm 1.55 \mathrm{IU} / \mathrm{mL}$ vs. $25.9 \pm 2.78 \mathrm{IU} / \mathrm{mL}$, respectively). Insulin is a regulator that stimulates the production of insulin-like growth factor-I (IGF-I) in granulosa cells (Matamoros, Cox, and Moore, 1991). Insulin-like growth factor-I is produced in follicles (Coleman et al. 2007) and corpus luteum (Woad et al. 2000) which is shown 
by the expression of IGF-I receptors on cumulus cells, granulosa cells, theca cells, and corpus luteum. IGF-I concentrations progressively increase during follicular growth to reach the dominant follicle until ovulation (Mao et al. 2004).
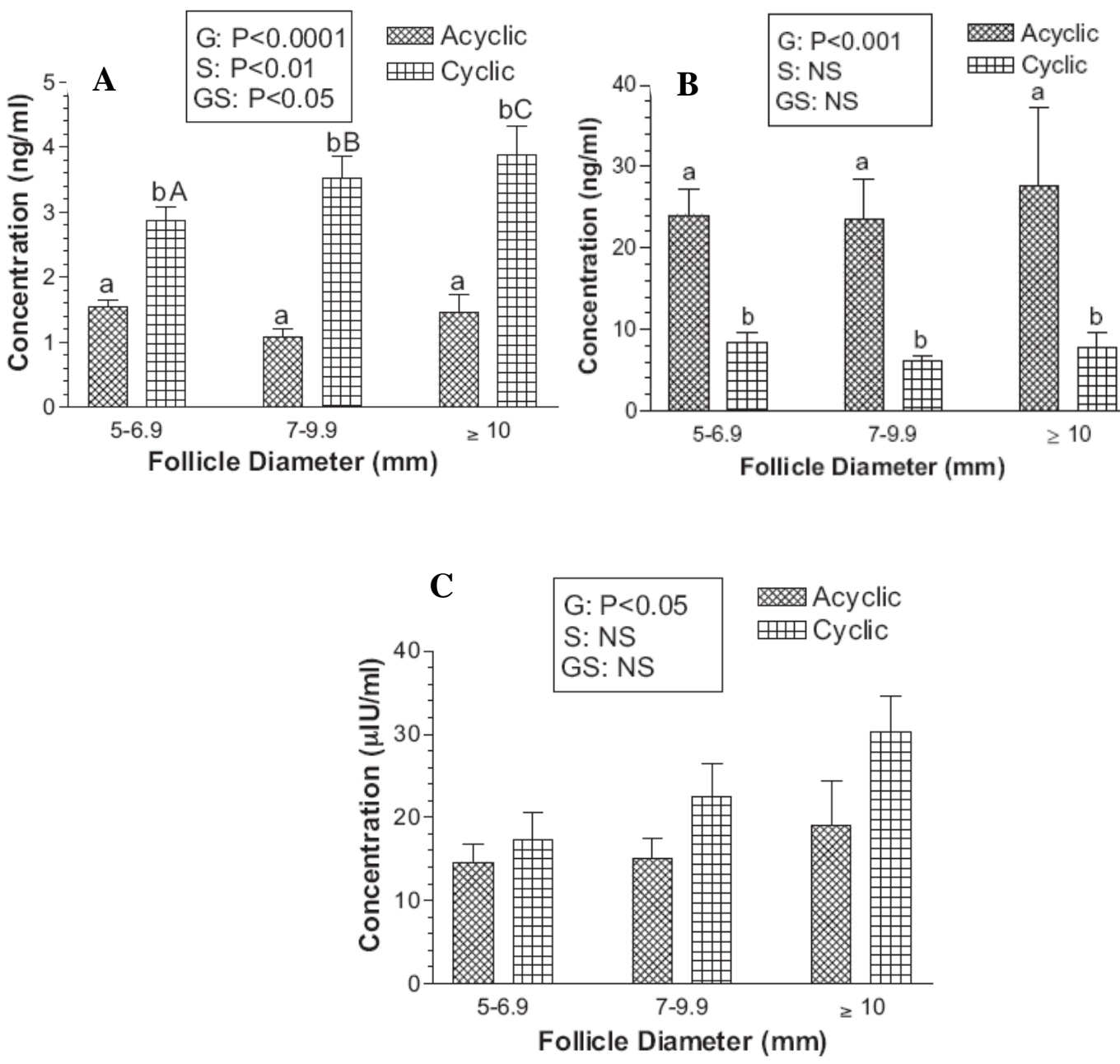

Figure 2. The concentration of (mean \pm SEM) estradiol (A), Concentration of (mean \pm SEM) progesterone (B), and concentration of (mean \pm SEM) insulin $(\mathrm{ng} / \mathrm{mL})(B)$ at different follicular sizes of buffalo which are cyclic and acyclic. Effect of a group $(\mathrm{G})$, follicular size (S), and group interaction with follicle size (GS) (Source: Khan et al., 2012)

\section{Monitoring Of Ovarium Activity In Dairy Cow}

The length of the estrous cycle did not differ between lactating and nonlactating dairy cows $(22.6 \pm 2.5 \mathrm{~d}$ vs. 21.3 $\pm 0.8 \mathrm{~d}$ ) (Endo et al., 2012). While the change in size/diameter of corpus luteum and the concentration of progesterone in blood plasma from $\mathrm{d} 0$ to $\mathrm{d} 14$ is presented in Fig 3. Endo et al. (2012) reported that by using ultrasonography, the development of corpus luteum (diameter of corpus luteum) in lactating dairy cows was greater than that of non-lactating on the 8 th $\mathrm{d}$ to the 14 th $\mathrm{d}(25.4 \pm 1.8 \mathrm{~mm}$ vs. $23.5 \pm 1.5 \mathrm{~mm})$.

Besides, there was a difference in the maximum diameter of the corpus luteum of lactating dairy cows which was greater than that of non-lactating $(26.3 \pm 2.5 \mathrm{~mm}$ vs. $23.9 \pm 1.5 \mathrm{~mm}$ ) and the maximum volume of the corpus luteum $(9239.0 \pm$ $2084.0 \mathrm{~mm} 3$ vs. $7182.7 \pm 1319.2 .7 \mathrm{~mm} 3)$. While the average concentration of progesterone in plasma samples collected from $\mathrm{d} 0$ to $\mathrm{d}$ seven did not differ between lactating cows and those who were not 
lactating $(1.6 \pm 1.2 \mathrm{ng} / \mathrm{mL}$ vs. $1.5 \pm$ $1.1 \mathrm{ng} / \mathrm{mL})$. However, the mean concentration of progesterone in plasma samples collected from the 8th d to the 14th $\mathrm{d}$ in lactating dairy cows was higher than that of non-lactating $(4.6 \pm 1.0 \mathrm{ng} / \mathrm{mL}$ vs. $3.9 \pm 0.9 \mathrm{ng} / \mathrm{mL}$ ). It was further reported that peak concentrations of estradiol during ovulation did not differ between lactating and non-lactating cows $(10.9 \pm 3.7 \mathrm{pg} / \mathrm{mL}$ vs. $12.4 \pm 4.1 \mathrm{pg} / \mathrm{mL}$ ). Based on Fig 3, the concentration of progesterone is positively correlated with the results of ultrasound size/diameter of corpus luteum both in lactation animals or not. The same thing was reported earlier by Luttgenau et al. (2011) that there is a positive relationship between the concentration of progesterone in plasma with the size of corpus luteum in the mid luteal phase in dairy cows.
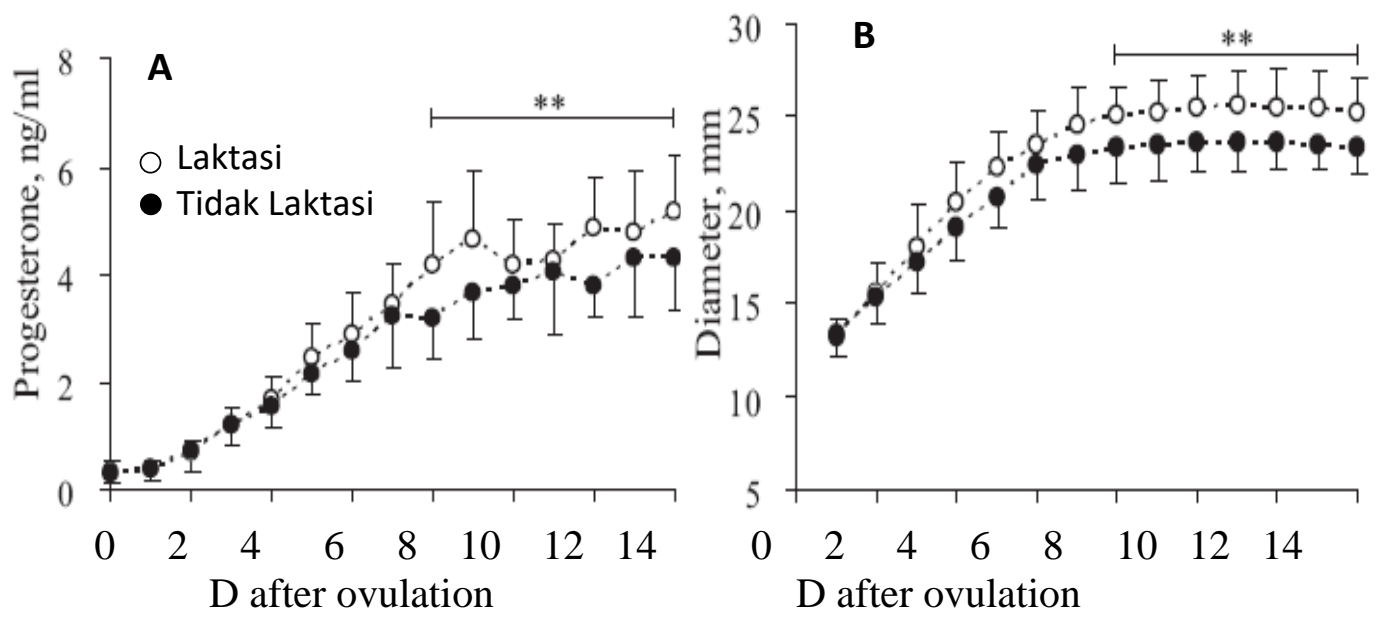

Figure 3. The concentration of progesterone in plasma (A) and the change in diameter of corpus luteum (B). The average of the corpus luteum diameter and the concentration of progesterone in plasma were highly significantly different $(* * \mathrm{P}<0.01)$

(Source: Endo et al., 2012)

\section{Monitoring Of Ovarium Activity In Sheep}

Prostaglandin F2 $\alpha$ and its synthesis (PG) are luteolytic agents that can cause rapid regression of corpus luteum, which are usually followed by estrus and ovulation. However, the use of prostaglandin $\mathrm{F} 2 \alpha$ can cause contamination by the presence of residues (Viñoles et al., 2011). Therefore, the use of $P G$ is an alternative method because PG can be rapidly metabolized in the lungs and does not accumulate in tissues (Fierro et al., 2013). The use of PG to control the estrous cycle in sheep is presented in Fig 4. Fig 4 showed that the injection of PG on $\mathrm{d}-2$ causes a decrease in the concentration of progesterone. Cárdenas, Wiley, and Pope (2004) reported that the decrease in progesterone concentration occurred after corpus luteum luteolysis. Corpus luteum regression is generally achieved from 6 to $24 \mathrm{~h}$ after PG injection (Wiley, Cárdenas, and Pope, 1997). While the concentration of estradiol from d -2 to -1 increased from 7 to $8 \mathrm{pmol} / \mathrm{L}$ in the control group and 8.5 to $11 \mathrm{pmol} / \mathrm{L}$ in the treatment group and tended to be constant on $\mathrm{d}-1$ to 0 (Fierro et al., 2013). This showed that the concentration of estradiol is positively correlated with the growth of ovulatory follicles, it is seen that with the growth of ovulatory follicles, the concentration of estradiol hormone tends to increase. Liu et al. (2006) reported that increasing the concentration of estradiol after luteolysis can stimulate changes in endogenous FSH patterns that will affect the follicle recruitment process and accelerate ovulatory follicle rupture. 


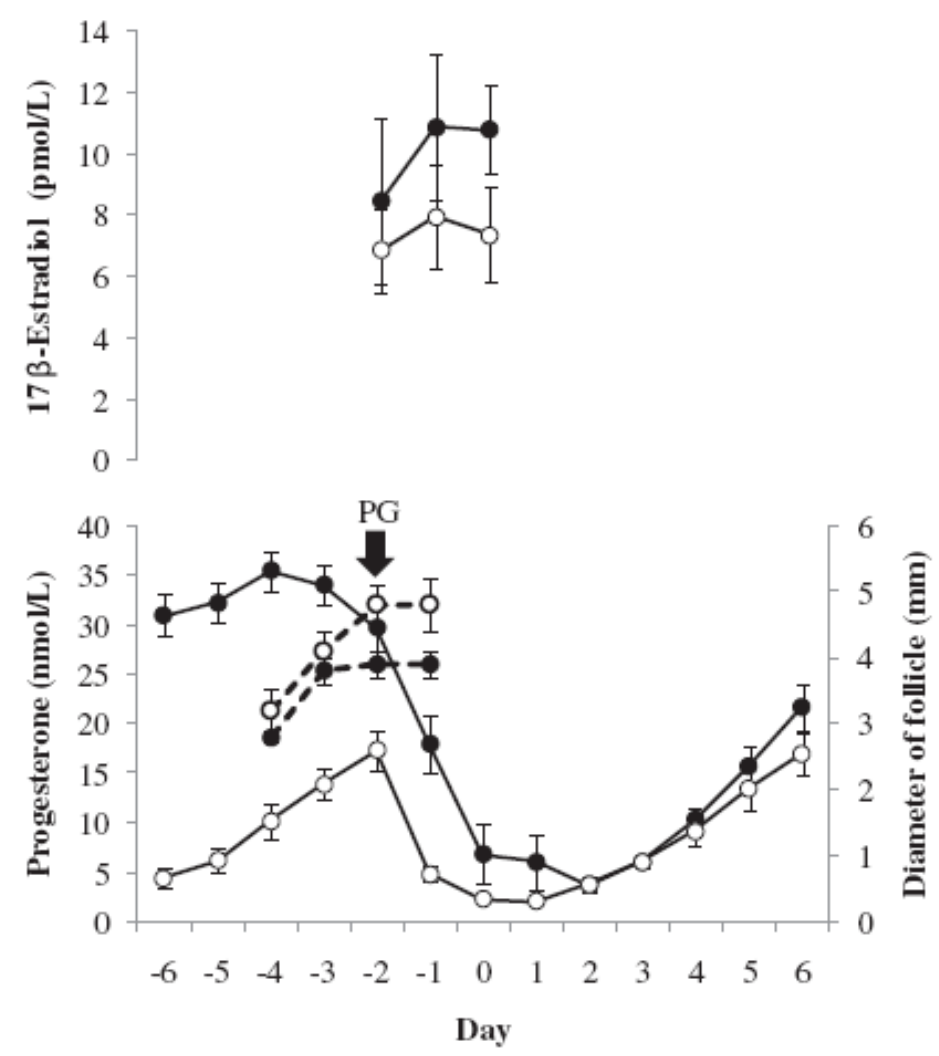

Figure 4. Concentration of progesterone (-) from d -6 to 6, ovulatory follicle growth (---), and concentration of plasma estradiol $48 \mathrm{~h}$ before insemination (d 0). Treatment

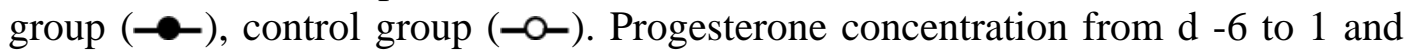
ovulatory follicular growth on $\mathrm{d}-2$ and -1 were significantly different $(\mathrm{P}<0.05)$

(Source: Fierro et al., 2013).

\section{Monitoring Of Ovarium Activity In Unta}

Camels are generally known as animals with low reproductive efficiency. One contributing factor is the inability to detect estrus accurately and efficiently. The estrous signs in camels do not always correlate with follicular status in the ovary. Therefore, estrous behavior cannot be used as a basis for determining the right time to mating in camel (Skidmore, Billah, and Allen, 1996).

Transrectal ultrasonography is one technique that can be used to monitor follicular growth and determine the optimum time to mate when a dominant follicle reaches a diameter of 13-18 mm (Manjunatha et al., 2012). Monitoring follicular growth and corpus luteum formation is presented in Fig 5a, while the correlation between the size of corpus luteum (diameter) and the concentration of progesterone is presented in Fig 5b. Based on Fig $5 \mathrm{a}$ and $5 \mathrm{~b}$ showed that an increase in the size of corpus luteum (diameter) was followed by an increase in the progesterone concentration from d 1 to 7 after ovulation. Whereas after the 7th $\mathrm{d}$ after ovulation, the size of corpus luteum decreased and was followed by decreasing of progesterone concentration until the 10th d (Manjunatha et al., 2012).

This indicates that the concentration of progesterone is positively correlated with the size of the corpus luteum. The same thing has been reported previously by Nagy, Juhasz, and Wernery (2005) that there is a relationship between the diameter of corpus luteum with the concentration of progesterone in serum after ovulation induction. 

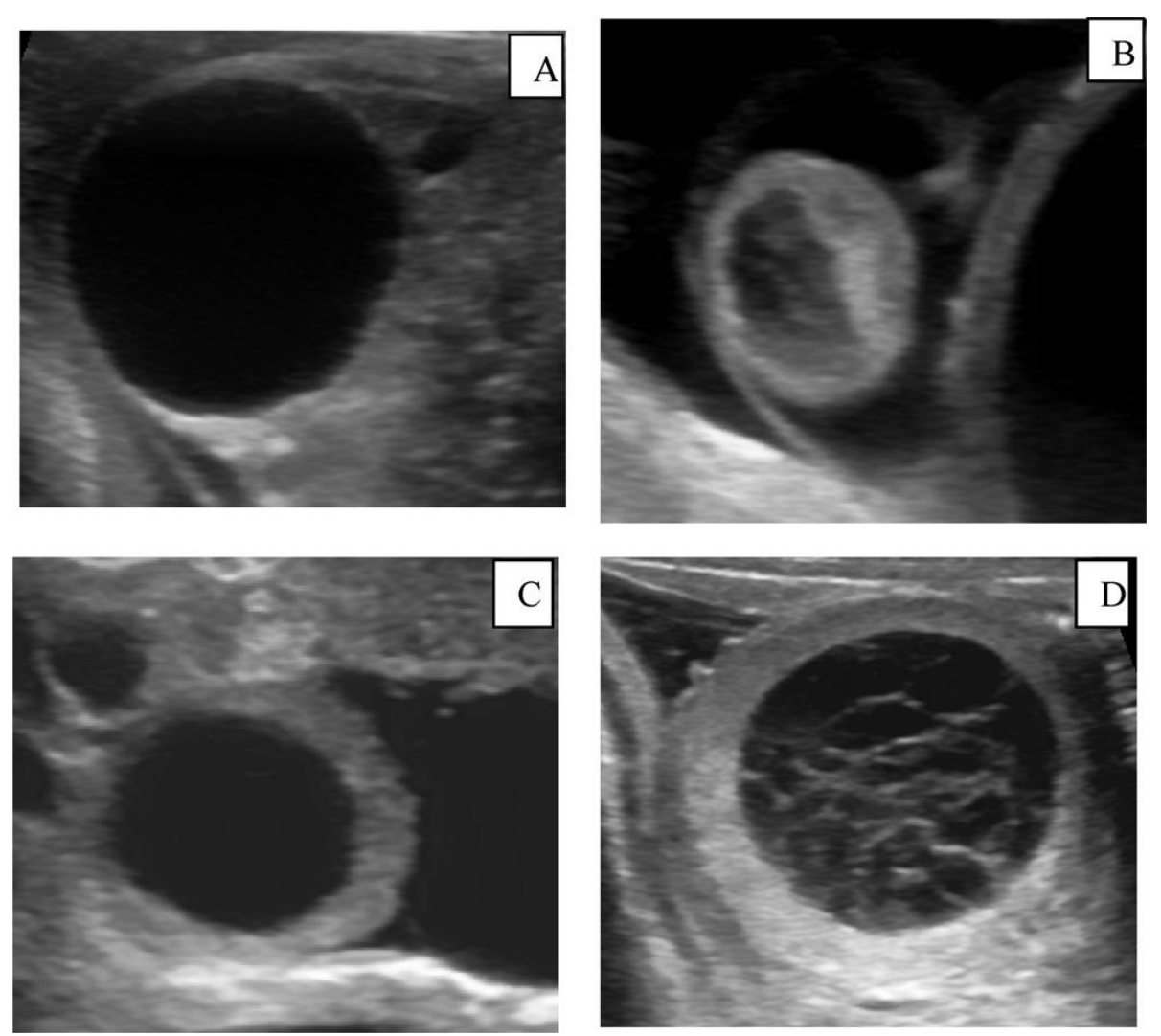

Figure 5a. Ultrasound images of the corpus luteum on camels. Dominant follicles (diameter $17 \mathrm{~mm}$ ) (A), Ovulation follicles on d 0 (B), corpus luteum growth on d 3 (C), and corpus luteum (diameter $25 \mathrm{~mm}$ ) on d 7

(Source: Manjunatha et al., 2012).

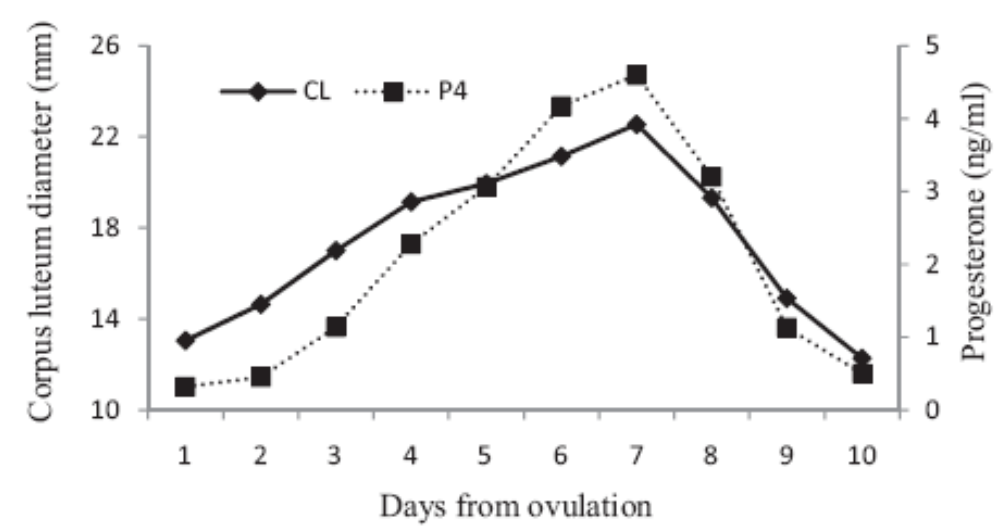

Figure 5b. Correlation between the size of the corpus luteum (diameter) and the concentration of progesterone in Camels

(Source: Manjunatha et al., 2012).

\section{CONCLUSION}

Monitoring of the estrous cycle in cyclic and non-cyclic buffaloes, lactating and non-lactating dairy cows, sheep injected with $\mathrm{PG}$, and camels provide the same picture between hormonal examination results (estradiol, progesterone, insulin, FSH, and $\mathrm{LH}$ ) with ultrasonography (follicular diameter, follicular area, corpus luteum area, and corpus luteum diameter).

\section{REFERENCES}

Ball, P. J., \& Peters, A. (2004). Reproduction in Cattle (3rd ed.). Blackwell Publishing Ltd. 
Bridges, A. (2010). Basics of Estrous Synchronization in Beef Cattle.

Cárdenas, H., Wiley, T. M., \& Pope, W. F. (2004). Prostaglandin F2 $\alpha$-induced estrus in ewes exhibiting estrous cycles of different duration. Theriogenology, 62(1-2), 123-129. https://doi.org/10.1016/j.theriogenolo gy.2003.08.020

Coleman, N. V., Shagiakhmetova, G. A., Lebedeva, I. Y., Kuzmina, T. I., \& Golubev, A. K. (2007). In vitro maturation and early developmental capacity of bovine oocytes cultured in pure follicular fluid and supplementation with follicular wall. Theriogenology, 67(5), 1053-1059. https://doi.org/10.1016/j.theriogenolo gy.2006.10.019

Das, G., \& Khan, F. (2010). Summer anoestrus in buffalo - a review. Reproduction in Domestic Animals, 45(6), 483-494. https://doi.org/10.11 11/j.1439-0531.2010.01598.x

Eissa, H. M. (1996). Concentrations of steroids and biochemical constituents in follicular fluid of buffalo cows during different stages of the oestrous cycle. British Veterinary Journal, 152(5), 573-581. https://doi.org/10.1 016/S0007-1935(96)80009-1

Endo, N., Nagai, K., Tanaka, T., \& Kamomae, H. (2012). Comparison between lactating and non-lactating dairy cows on follicular growth and corpus luteum development, and endocrine patterns of ovarian steroids and luteinizing hormone in the estrous cycles. Animal Reproduction Science, 134(3-4), 112-118. https://doi.org/10. 1016/j.anireprosci.2012.08.018

Fierro, S., Gil, J., Viñoles, C., \& OliveraMuzante, J. (2013). The use of prostaglandins in controlling estrous cycle of the ewe: A review. Theriogenology, 79(3), 399-408. https://doi.org/10.1016/j.theriogenolo gy.2012.10.022

Hafez, E. S., Jainudeen, M., \& Rosnina, Y. (2000). Hormones, Growth Factors and Reproduction. In E. S. Hafez \& B. Hafez (Eds.), Reproduction in Farm Animals (7th ed., pp. 33-54). Lippincott, Williams and Wilkins, Baltimore, MA.

Khan, F. A., Das, G. K., Pande, M., Sarkar, M., Mahapatra, R. K., \& Shankar, U. (2012). Alterations in follicular fluid estradiol, progesterone and insulin concentrations during ovarian acyclicity in water buffalo (Bubalus bubalis). Animal Reproduction Science, 130(1-2), 27-32. https://doi. org/10.1016/j.anireprosci.2011.12.020

Liu, X., Dai, Q., Hart, E. J., Duggavathi, R., Barrett, D. M. W., Rawlings, N. C., \& Bartlewski, P. M. (2006). Ovarian and endocrine responses to prostaglandin $\mathrm{F} 2 \alpha$ (PGF2 $\alpha$ ) given at the expected time of the endogenous FSH peak at mid-cycle in ewes. Theriogenology, 66(4), 811-821. https://doi.org/10.1016/j.theriogenolo gy.2006.01.057

Lüttgenau, J., Ulbrich, S. E., Beindorff, N., Honnens, A., Herzog, K., \& Bollwein, H. (2011). Plasma progesterone concentrations in the mid-luteal phase are dependent on luteal size, but independent of luteal blood flow and gene expression in lactating dairy cows. Animal Reproduction Science, 125(1-4), 20-29. https://doi.org/10.10 16/j.anireprosci.2011.02.002

Manjunatha, B. M., David, C. G., Pratap, N., Al-Bulushi, S., \& Hago, B. E. (2012). Effect of progesterone from induced corpus luteum on the characteristics of a dominant follicle in dromedary camels (Camelus dromedarius). Animal Reproduction Science, 132(3-4), 231236. https://doi.org/10.1016/j.anirepro sci.2012.05.016

Mao, J., Smith, M. F., Rucker, E. B., Wu, G. M., McCauley, T. C., Cantley, T. C., Prather, R. S., Didion, B. A., \& Day, B. N. (2004). Effect of epidermal growth factor and insulinlike growth factor I on porcine preantral follicular growth, antrum 
formation, and stimulation of granulosal cell proliferation and suppression of apoptosis in vitro1. Journal of Animal Science, 82(7), 1967-1975. https://doi.org/10.2527/2 004.8271967x

Matamoros, I. A., Cox, N. M., \& Moore, A. B. (1991). Effects of exogenous insulin and body condition on metabolic hormones and gonadotropin-induced follicular development in prepuberal gilts. Journal of Animal Science, 69(5), 2081-2091. https://doi.org/10.2527/19 91.6952081x

Nagy, P., Juhasz, J., \& Wernery, U. (2005). Incidence of spontaneous ovulation and development of the corpus luteum in non-mated dromedary camels (Camelus dromedarius). Theriogenology, 64(2), 292-304. https://doi.org/10.1016/j.ther iogenology.2004.11.020

Nanda, A., Brar, P., \& Prabhakar, S. (2019). Enhancing reproductive performance in dairy buffalo: major constraints and achievements. Bioscientifica Proceedings, 61, 27-36. https://doi.org/10.1530/biosciprocs.5.003

Nebel, R. L., Walker, W. L., McGilliard, M. L., Allen, C. H., \& Heckman, G. S. (1994). Timing of artificial insemination of dairy cows: fixed time once daily versus morning and afternoon. Journal of Dairy Science, 77(10), 3185-3191. https://doi.org/ 10.3168/jds.S0022-0302(94)77261-1

Sahatpure, S., \& Patil, M. (2008). Demonstration of hormone application in animal growth. Veterinary World, 1 , 203-204.

Senger, P. (2005). Pathways to pregnancy and parturition (2nd ed.). Current Conceptions Inc.
Skidmore, J. A., Billah, M., \& Allen, W. R. (1996). The ovarian follicular wave pattern and induction of ovulation in the mated and non-mated one-humped camel (Camelus dromedarius). Reproduction, 106(2), 185-192. https://doi.org/10.1530/jrf.0.1060185

Viñoles, C., Paganoni, B., Milton, J. T. B., Driancourt, M. A., \& Martin, G. B. (2011). Pregnancy rate and prolificacy after artificial insemination in ewes following synchronisation with prostaglandin, sponges, or sponges with bactericide. Animal Production Science, 51(6), 565-569. https://doi. org/10.1071/AN10200

Wiley, T. M., Cárdenas, H., \& Pope, W. F. (1997). Effect of the rate of progesterone decline at luteolysis on the ovulatory follicles and subsequent estrous cycle length in ewes. Animal Reproduction Science, 46(1-2), 7987. https://doi.org/10.1016/S0378-43 20(96)01602-8

Woad, K., Baxter, G., Hogg, C., Bramley, T., Webb, R., \& Armstrong, D. (2000). Expression of mRNA encoding insulin-like growth factors I and II and the type 1 IGF receptor in the bovine corpus luteum at defined stages of the oestrous cycle. Reproduction, 120(2), 293-302. https: //doi.org/10.1530/reprod/120.2.293

Zicarelli, L. (2010). Enhancing reproductive performance in domestic dairy water buffalo (Bubalus bubalis). In M. Lucy, J. Pate, M. Smith, \& T. Spencer (Eds.), Reproduction in Domestic Ruminants VII (pp. 443456). Nottingham University Press. https://doi.org/10.7313/UPO9781907 284991.034 